\title{
MENINGKATKAN KEMAMPUAN MOTORIK HALUS ANAK MELALUI PERMAINAN LEGO BLOCK
}

\author{
Sarah Nandya Mutiara \\ Universitas Pendidikan Indonesia, Jln. Setiabudhi no. 229 Bandung
}

\begin{abstract}
Improving Children's Fine Motor Skills Through Lego Block Games. The research was conducted based on the problems found among children of Early Childhood Education (Indonesian, and henceforth, PAUD) Post Miana V, namely the low fine motor skills, especially in creating objects according to various media, creating two forms from blocks, and building a tower of a minimum of 8 (eight) cubes. In response to these problems, improvements in instruction are required. In this research, the researcher designed Lego block games to improve group A students' fine motor skills. The research aims to find about the profile of children's fine motor skills before the implementation of Lego block games, the implementation of Lego block games, and the improvement of group A students' fine motor skills after the implementation of Lego block games in PAUD Post Miana V. It adopted classroom action research method. The subjects were 8 (eight) children of group A PAUD Post Miana V. The findings show that after the implementation of Lego block games, there were significant improvements in the fine motor skills of group A students of PAUD Post Miana V. The improvements were most observable in the increasing number of children who reached the stages of beginning to develop and developing according to expectation. Based on these results, Lego block games can be used as an effective learning method to improve kindergarten children's fine motor skills.
\end{abstract}

Keywords : fine motor skills, lego block games.

\begin{abstract}
Abstrak : Meningkatkan Kemampuan Motorik Halus Anak Melalui Permainan Lego Block. Penelitian ini di lakukan atas dasar permasalahan yang muncul pada anak Pos PAUD Miana V yaitu rendahnya kemampuan motorik halus anak, menciptakan sesuai dengan berbagai media, mencipta 2 bentuk dari balok, menyusun menara kubus minimal 8. Tindak lanjut dari permasalahan tersebut perlu adanya perbaikan pembelajaran. Peneliti merancang penelitian melalui permainan lego block untuk meningkatkan kemampuan motorik halus anak kelompok A. Tujuan dari penelitian ini untuk mengetahui profil kemampuan motorik halus anak sebelum diterapkan permainan lego block, mengetahui bagaimana penerapan permainan lego block, dan mengetahui peningkatan kemampuan motorik halus anak kelompok A sesudah diterapkan permainan lego block di Pos PAUD Miana V. Metode penelitian yang di gunakan adalah Penelitian Tindakan Kelas (PTK). Subjek pada penelitian ini adalah anak kelompok A Pos PAUD Mianan V berjumlah 8 anak. Kondisi akhir kemampuan motorik halus menunjukan terdapat peningkatan yang signifikan terhadap kemampuan motorik halus anak kelompok A Pos PAUD Mianan V setelah diterapkan permainan lego block. Peningkatan kemampuan terlihat dari semakin banyaknya anak yang sudah mencapai tahap mulai berkembang (MB) dan berkembang sesuai harapan (BSH). Berdasarkan hasil penelitian permainan lego block dapat di gunakan sebagai metode pembelajaran yang efektif untuk meningkatkan kemampuan motorik halus anak TK.

Kata Kunci : kemampuan motorik halus, permainan lego blok
\end{abstract}



Perkembangan fisik pada masa kanak-kanak ditandai dengan berkembangnya kemampuan motorik. Menurut Samsudin (2005, hlm. 9) motorik merupakan istilah umum untuk berbagai perilaku gerak manusia perkembangan motorik anak taman kanak-kanak merupakan perubahan kemampuan motorik dari bayi sampai dewasa yang melibatkan berbagai aspek perilaku dan kemampuan motorik. Perkembangan motorik meliputi perkembangan motorik kasar dan motorik halus. Menurut Wahyudin dan Agustin (2012, hlm. 34-35) Motorik kasar adalah gerakan-gerakan tubuh yang melibatkan otot-otot besar atau sebagaian besar otot yang ada dalam tubuh maupun seluruh anggota tubuh yang dipengaruhi oleh kematangan diri sejalan dengan Suyanto (2005, hlm. 51) motorik kasar merupakan gerakan yang mengunakan otot-otot besar seperti berjalan, berlari dan melompat.

Kemampuan motorik halus menurut Sujiono (2008, hlm. 1.13) kemampuan yang gerakannya hanya melibatkan bagian-bagian tubuh tertentu saja dan dilakukan oleh otototot kecil, seperti kemampuan mengunakan jari jemari tangan dan gerakan pergelangan tangan yang tepat. Sedangkan menurut Daeng (1996, hlm. 121) menyebutkan bahwa yang disebut motorik halus adalah aktivitas motorik yang melibatkan otot-otot kecil atau halus, gerakan ini menungtut koordinasi mata dan tangan dan kemampuan pengendalian gerak baik yang memungkinkanya untuk melakukan kecermatan dalam gerakanya. Beberapa gerakan yang termasuk kedalam kemampuan motorik halus adalah mengunting, merobek, meremas, menggambar, menulis, melipat, meronce, menjahit, menggenggam, menyusun balok dan lain sebagainya (Suyanto, 2005, hlm. 51)
Perkembangan motorik merupakan salah satu faktor yang terpenting dalam perkembangan individu yang mempengaruhi perkembangan selanjutnya. Permasalahan yang mungkin terjadi apabila kemampuan motorik halus anak kurang dilatih dikhawatirkan anak akan kurang mampu mengfungsikan otot-otot kecil dalam menggerakan jari dan kedua tanganya, anak kurang mampu mengkoordinasikan kecepatan tangan (Yudha dan Rudiyanto, 2005, hlm 15). Melihat dampak negatif dari kurangnya stimulus motorik halus, maka dari itu penting untuk meningkatkan kemampuan motorik halus anak sejak dini.

Setelah mengetahui permasalahan umum diatas, jika dilihat dilapangan sebagaian TK menerapkan pemebelajaran yang dijadikan dasar peningkatan motorik halus masih kurang terencana dan terprogram. Guru masih menerapkan pembelajaran yang bersifat konvensional seperti pembelajaran yang kurang memunculkan minat anak dan dengan kegiatan meyentuh, meraba, memegang bagi anak usia dini dapat melalui kegiatan bermain lego Block.

Peningkatan kemampuan motorik halus pada anak usia dini dapat di lakukan dalam berbagai kegiatan seperti kegiatan kolase, mozaik, meronce, bermain balok, menganyam, kirigami dll. Upaya meningkatkan kemampuan motorik halus anak kelompok A dalam penelitian ini dilakukan mengunakan permainan lego block. Pemilihan permainan lego block sebagai tindakan yang dilakukan untuk meningkatkan kemampuan motorik halus anak karena permainan lego block merupakan permainan yang menyenangkan bagi anak karena permainan lego block mudah untuk dilakukan anak, media lego block ringan, memiliki warna yang cerah dan bentuknya bermacam-macam sehingga 
mudah untuk di pegang, di bentuk dan di mainkan oleh anak serta kegiatan permainan lego block belum pernah dilakukan di Pos PAUD Miana V, selain itu Latif dkk menyatakan bahwa permainan lego block dapat meningkatkan kekuatan dan koordinasi motorik halus pada anak.

Permainan lego Block menurut Sudono (2000) menyatakan permainan yang memiliki kegiatan memasang, memadukan, membangun, dan menumpuk dapat menjadikan kreativitas dan motorik halus semakin berkembang. Menurut Latif, Zukhairina, Zubaidah, dan Afandi (2013) lego Block merupakan salah satu bentuk alat permainan pembangunan dan alat main pembangunan berfungsi untuk mengembangkan aspek sosial emosional dalam hubungan dengan teman sebaya, meningkatkan bahasa dalam kemampuan berkomunikasi, meningkatkan kekuatan dan koordinasi motorik halus dan kasar serta dapat meningkatkan perkembangan aspek kognitif seperti mengenal konsep, bentuk, pengetahuan, dan pemetaan.

\section{METODE}

Metode yang akan di gunakan dalam penelitian ini adalah penelitian tindakan kelas (Classroom Action Research) yang akan di lakukan secara kolaboratif. Penelitian secara Kolaboratif ini dilaksanakan oleh peneliti dan berkolaborasi dengan guru adapun kolaborasi yang di lakukan adalah bentuk kerjasama antara peneliti dengan guru kelas kelompok A dalam merancang, melaksanakan dan merefleksikan tindakan dengan tujuan untuk memperbaiki atau meningkatkan pembelajaran di dalam kelas. Penelitian tindakan kelas menurut Mulyasa (2012, hlm.11). "bahwa penelitian tindakan kelas merupakan suatu upaya untuk mencermati kegiatan belajar sekelompok peserta didik dengan memberikan sebuah tindakan (treatment) yang sengaja dimunculkan. Tindakan tersebut dilakukan oleh guru, oleh guru bersama-sama dengan peserta didik, atau oleh peserta didik di bawah bimbingan dan arahan guru, dengan maksud untuk memperbaiki dan meningkatkan kualitas pembelajaran".

Desain penelitian yang akan digunakan dalam penelitian ini adalah "model yang dikembangkan oleh Kemmis dan Mc Taggart" (dalam Arikunto, 2010, hlm. 137). Pelaksanakaan penelitian ini terjadi dalam beberapa siklus yang saling berkaitan dengan setiap tahapanya yaitu perencanaan (planning), tindakan (acting), pengamatan (observating), dan refleksi (reflecting) kemudian diikuti dengan adanya perencanaan ulang atau revisi terhadap pelaksanaan siklus sebelumnya untuk melanjutkan pada siklus selanjutnya.

\section{HASIL DAN PEMBAHASAN}

Profil Keterampilan Motorik Halus Anak Kelompok A Pos PAUD Miana V pada Observasi Awal

Berdasarkan hasil pengamatan pada observasi awal ditemukan bahwa rata-rata keterampilan motorik halus anak kelompok A masih dalam kategori belum berkembang, hal ini di lihat dari anak belum dapat menciptakan sesuatu dengan berbagai media seperti, menyusun menara dari kubus minimal 8 kubus, mencipta 2 bentuk bangunan dari balok, mencipta 2 bentuk dari kepingan geometri, serta kegiatan yang mencakup pengkoordinasian mata dan tangan. Tindaklanjut dari permasalahan tersebut adalah perbaikan pembelajaran untuk menigkatkan keterampilan motorik halus anak kelompok A. Dari jumlah peserta 
didik 8 anak, yang termasuk kategori belum berkembang (BB) 100\%, pada kategori mulai berkembang (MB) 0\%. Sementara pada kategori berkembang sesuai harapan (BSH) belum terdapat anak yang memiliki keterampilan motorik halus dalam kategori BSH atau $0 \%$.

Penerapan Permainan Lego Block Untuk Meningkatkan Keterampilan Motorik Halus Anak Kelompok A di Pos PAUD Miana V

Berdasarkan observasi awal, maka peneliti merancang untuk meningkatkan keterampilan motorik halus anak Kelompok A Pos PAUD Miana V melalui penerapan permainan lego block dengan metode penelitian tindakan kelas secara kolaboratif yang di laksanakan dalam dua siklus dengan setiap siklus terdiri dari dua tindakan. Kegiatan yang di lakukan dalam siklus I dan siklus II dilaksanakan dengan tema "Aku", dalam setiap siklus kegiatan di laksanakan secara individu karena keterampilan yang akan di latih mencakup keterampilan motorik halus setiap anak. Setiap satu tindakan terdapat empat tahapan kegiatan yaitu: tahapan perencanaan, tahapan tindakan, tahapan observasi/ pengamatan, dan tahapan refleksi, kegiatan dalam setiap tindakan adalah sebagai berikut: Pelaksanaan siklus I anak masih mengalami kesulita saat kegiatan bermain lego block, bentuk lego block yang dibuat anak terjatuh terus menerus dan hanjur, susunan lego block yang dibuat tidak tersabung satu sama lain karena saat membentuk anak kurang menekan lego block. Pelaksaan siklus II anak semakin baik saat melakukan kegiatan bermain lego block karena bentuk yang dibuat anak semakin kokoh dan tidak terjatuh. Permainan lego block dimainkan dengan cara anak mengambil lego block, memegang lego block dan menggengam lego block membentuk dengan cara menekan lego block dan mencabut lego block yang telah di susun.

\section{Peningkatan Keterampilan Motorik} Halus Anak Kelompok A Pos PAUD Miana V Setelah Diberikan Permainan Lego Block

Setelah melakukan beberapa tindakan terdapat peningkatan yang cukup signifikan dalam keterampilan motorik halus anak melalui kegiatan permainan lego block pada kelompok A Pos PAUD Miana V, pada siklus I dan Sikulus II secara menyeluruh perkembangan keterampilan motorik halus melalui permainan lego block dapat dilihat dalam diagram batang dibawah ini:

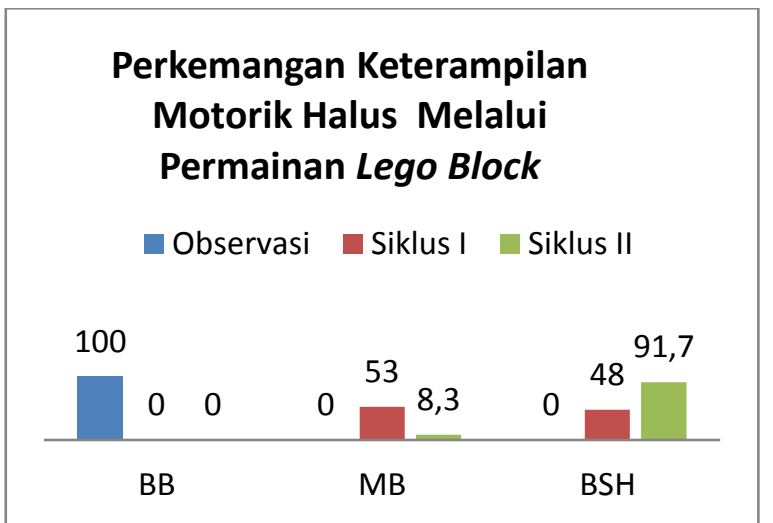

Diagram 1. Perkembangan Keterampilan

$$
\begin{aligned}
& \text { Motorik Halus } \quad \text { Melalui } \\
& \text { Permainan Lego Blok }
\end{aligned}
$$

Tindakan yang telah diberikan pada siklus I dan siklus II untuk meningkatkan keterampilan motorik halus anak kelompok A melalui permainan lego block. Berdasarkan diagram diatas terjadi peningkatan pada setiap kategori disetiap siklus, berikut merupakan pemaparan persentasi. Kategori belum berkembang (BB) pada observasi awal $100 \%$ setelah diberikan tindakan pada akhir siklus I 
menjadi $0 \%$ pada akhir siklus II menjadi 0\%, kategori mulai berkembang (MB) saat observasi awal $0 \%$ setelah diberikan tindakan pada akhir siklus I menjadi 53\% pada akhir siklus II menjadi 8,3\% sementara kategori berkembang sesuai harapan (BSH) pada observasi awal sebesar $0 \%$ setelah diberikan tindakan pada akhir siklus I meningkat menjadi $48 \%$ pada akhir siklus II semakin meningkat menjadi $91,7 \%$.

\section{Profil Keterampilan Motorik Halus Anak Kelompok A Sebelum Diberikan Permainan Lego Block.}

Berdasarkan pengamatan pada observasi awal ditemukan bahwa rata-rata keterampilan motorik halus anak kelompok A di Pos PAUD Miana V masih dalam kategori belum berkembang hal ini dilihat dari anak belum dapat menciptakan sesuatu dengan berbagai media seperti, menyusun menara dari kubus minimal 8 kubus, mencipta 2 bentuk bangunan dari balok, mencipta 2 bentuk dari kepingan geometri, serta kegiatan yang mencakup pengkoordinasian mata dan tangan. Keterampilan motorik halus anak saat observasi awal yang termasuk kategori belum berkembang (BB) 100\%, kategori mulai berkembang (MB) sebesar 0\%, dan pada kategori berkembang sesuai harapan (BSH) $0 \%$ berdasarkan hasil diatas perlu adanya tindaklanjut untuk meningkatkan ketrampilan motorik halus anak kelompok A. Berikut adalah data anak yang masih memerlukan stimulasi dalam keterampilan motorik halus: AF, AN, FD, FT, NN, SY, YA, YS.

Berdasarkan pengamatan di Pos PAUD Miana V, sejauh ini penyelenggaraan kegiatan motorik halus masih rendah. Salah satu penyebab yaitu kurangnya media pembelajaran, metode, pengelolaan siswa, dan pengelolaan kelas. Media dan metode pembelajaran yang di gunakan monoton dan kurang berfariasi, menurut Hurluck (1978, hlm. 171) menyatakan bahwa hal-hal penting dalam mempelajari keterampilan motorik adalah kesiapan dan kesempatan belajar, motivasi, model yang baik, dan bimbingan.

Pengelolaan siswa menurut Suyanto dan Jihad (2013, hlm. 81) hal mendasar yang harus di kembangkan agar siswa dapat bergerak aktif ketika ia sedang belajar dengan memanfaatkan indra sebanyak mungkin dan membuat seluruh tubuh serta pikiran terlibat dalam seluruh proses pembelajaran, dan menurut Masitoh (2008, hlm. 5.7) mengatakan anak adalah pembelajar yang aktif, hal terpenting ketika mengatakan anak aktif, yang terpenting yang perlu kita perhatikan adalah sifat-sifat multi dimensional dari aktifitas anak tersebut. Pertama ketika mereka bergerak mereka mencari stimulasi yang dapat meningkatkan kesempatan anak untuk belajar, kedua anak mengunakan seluruh tubuhnya sebagai alat untuk belajar dan melibatkan semua alat indranya seperti merasakan, menyentuh, mendengarkan, melihat dan mengamati suatu objek, atau melakukan eksplorasi. Ketiga anak adalah peserta yang aktif dalam mencari pengalamanya sendiri.

Pengelolaan kelas menurut Suyanto dan Jihad (2013, hlm. 102-107) adalah upaya yang dilakukan guru untuk mengkondisikan kelas dengan mengoptimalkan berbagai sumber (potensi pada diri guru, saranan dan lingkungan belajar) dikelas yang ditujuan agar proses belajar mengajar dapat disesuaikan dengan perencanaan dan tujuan yang ingin dicapai. Untuk dapat mencapai tujuan pembelajaran diperlukan media perantara yang dapat digunakan untuk merangsang pemikiran dan keinginan anak. Pengunaan media secara 
kreatif memungkinkan siswa untuk belajar lebih baik dan dapat menstimulasi anak untuk mencapai tujuan yang di harapkan. Menurut Heinich, Molenda, dan Russell (dalam Eliyawati, 2005, hlm. 104-106) media merupakan alat saluran komunikasi, yaitu sebagai pembawa pesan yang oleh sumber pesan (komunikator) menuju penerima pesan (komunikan).

$$
\text { Upaya untuk meningkatkan }
$$
keterampilan motorik halus anak kelompok A Pos PAUD Miana V peneliti akan memberikan tindakan melalui permainan lego block. Menurut Hurlock (dalam Ismail, 2006, hlm. 29) menyatakan aktivitas bermain memiliki pengaruh yang sangat besar terhadap perkembangan fisik aktifitas bermain penting bagi anak untuk mengembangkan otot dan melatih seluruh bagian tubuhnya dengan bermain anak akan bertambah pengalaman dan pengetahuanya. Menurut Ismail (2006, hlm. 129) kegiatan bermain dari segi pendidikan adalah permainan yang memberikan peluang kepada anak untuk bersuakarya, untuk melakukan dan menciptakan sesuatu dari permainan itu dengan tanganya sendiri.

Kegiatan bermain yang dapat memberian peluang kepada anak untuk bersuakarya, mencipta sesuatu dapat dilakukan melalui permainan bongkar pasar balok pelastik (lego block). Permainan lego Block menurut Sudono (2000) menyatakan permainan yang memiliki kegiatan memasang, memadukan, membangun, dan menumpuk dapat menjadikan kreativitas semakin berkembang.

\section{Pelaksanaan Pembelajaran Melalui Permainan Lego Block Untuk Meningkatkan Keterampilan Motorik Halus Anak Di Kelompok A Pos PAUD Mianan V}

Upaya meningkatkan keterampilan motorik halus anak kelompok A di Pos PAUD Miana $\mathrm{V}$ dengan mengunakan permainan lego block dilaksanakan dalam dua siklus, dimana siklus I dilaksanakan dengan dua tindakan begitu pula dengan siklus II, kegiatan pembelajaran di laksanakan secara individu. Kegiatan pada setiap siklus dilakukan secara bertahap, sebelum melakukan tindakan peneliti melakukan diskusi dan berkolaborasi dengan guru kelas tentang perencanaan tindakan, kemudian membuat rancangan dengan menyusun rancangan kegiatan harian (RKH) dan skenario pembelajaran sebagai acuan bagi pelaksana bagi setiap tindakan yang akan di lakukan. Sebelum merancang rencana pembelajaran, peneliti melakukan diskusi dengan guru kelas, dalam setiap tindakan peneliti berkolaborasi dengan guru kelas serta dalam melakukan refleksi terhadap kegiatan yang telah di laksanakan.

Menurut Andriewongso (dalam Essa, 2010) permainan lego block merupakan permainan bongkar pasang balok warna. Menurut Rosita (2014) bermain lego block dalam mengembangkan aspek kognitif sangat penting, karena dengan bermain lego block anak dapat mengenal warna, bentuk dan ukuran serta dapat membuat berbagai bentuk dan ukuran yang ia inginkan sehingga dapat mengembangkan kreativitas.

Pelaksanaan penelitian yang di lakukan berlangsung selama 2 minggu. Peningkatan keterampialan motorik halus anak kelompok A Pos PAUD Miana V berlangsung lancar. Meningkatnya keterampilan motorik halus dalam kegiatan bermain lego block dapat dilihat dalam hasil kegiatan dari setiap siklusnya dan hasil refleksi guru kelas dan peneliti.

Awal pelaksanaan siklus I tindakan I anak masih terlihat asing saat kegiatan bermain lego block, karena kegiatan bermain 
lego block merupakan kegiatan yang baru bagi anak kelompok A. saat bermain lego block anak masih ragu-ragu untuk bermain dan hanyak memegang lego block, setelah diberikan motivasi oleh guru anak menjadi bersemangat dan mengikuti kegiatan bermain. Saat kegiatan bermain lego block anak belum dapat menghubungkan antara satu lego block dengan lego block yang lain, bentuk lego block yang di buat anak belum saling tersambung satu sama lain karena pada saat menyusun lego block anak kurang menekan lego block sehingga susunan lego block yang telah dibuat jatuh dan hancur.

Pelaksanaan siklus I tindakan II, anak terlihat antusias untuk bermain. Saat bermain lego block permasalahn yang di hadapi anak sama seperti siklus I tindakan I, saat menyusun kepingan lego block bentuk yang di buat anak jatuh dan hancur karena bangunan yang di buat anak menjulang tinggi ke atas dan pada saat menyusun lego block anak kurang menekan lego block sehingga susunan lego block yang di buat anak tidak berdiri dengan tegak dan terjatuh.

Pelaksanaan siklus II tindakan I, anak semakin luwes saat kegiatan bermain lego block. keterampilan motorik halus anak pada siklus II semakin berkembang hal ini dapat dilihat dari susunan lego block yang di buat anak semakin kokoh. Saat mencipta bentuk bangunan yang di buat anak semakin tinggi, dan tidak rubuh. Pada siklus II tindakan II selain minat dan antusias anak dalam kegiatan bermain lego block pada siklus II tindakan II kemampuan bersosialisasi dan kerjama pada anak semakin terlihat, karena pada siklus II tindakan II di laksanakan pada ruangan yang tidak terdapat meja dan kursi sehingga ruang gerak anak semakin.

Permainan lego block tidah hanya dapat mengembangkan keterampilan motorik halus anak tetapi juga dapat mengembangkan keterampilan bahasa, kognitif, sosial emosi anak. Melalui permain lego block keterampilan bahasa anak semakin terlatih karena saat bermain anak saling berinteraksi dengan teman sebaya. Dengan permainan lego block keterampilan kognitif anak dapat berkembang melalui permainan lego block anak dapat mengenal bentuk, warna, ukuran. Sejalan dengan yang dikatakan Rosita (2014) bermain lego block dalam mengembangkan aspek kognitif sangat penting, karena dengan bermain lego block anak dapat mengenal warna, bentuk dan ukuran.

Seperti yang di katakan Latif, Zukhairina, Zubaidah, dan Afandi (2013) lego block merupakan salah satu bentuk alat permainan pembangunan dan alat main pembangunan berfungsi untuk mengembangkan aspek sosial emosional dalam hubungan dengan teman sebaya, meningkatkan bahasa dalam kemampuan berkomunikasi, meningkatkan kekuatan dan koordinasi motorik halusdan kasar serta dapat meningkatkan perkembangan aspek kognitif seperti mengenal konsep, bentuk, pengetahuan, dan pemetaan.

\section{Peningkatan Ketrerampilan Motorik Halus Anak Kelompok A Pos PAUD Miana V Setelah Diberikan Permainan Lego Block.}

Berdasarkan pengamatan pada observasi awal rata-rata keterampilan motorik halus anak kelompok A Pos PAUD Miana V masih dalam kategori belum berkembang, dari beberapa tindakan yang telah di berikan melalui permainan lego block keterampilan motorik halus anak mengalami peningkatan secara bertahap pada setiap tindakanya. Untuk meningkatkan keterampilan motorik halus anak dari satu tindakan ketindakan selnjutnya dilakukan refleksi, yang mengacu pada hasil observasi 
dengan memperhatika item mana yang harus ditingkatkan dan strategi apa yang harus di lakukan agar hasil yang diperoleh dalam tindakan berikutnya dapat meningkat. Hal ini sejalan dengan pendapat Arifin (2009) refelksi dilakukan untuk memudahkan peneliti dalam mengetahui bagian-bagian atau aspek-aspek dari evaluasi yang diangap masih lemah.

Pelaksanaan siklus I tindakan I kegiatan pembelajaran yang di lakukan belum maksimal karena kolabolator kurang jelas dalam memberikan instuksi kepada guru tentang kegiatan bermain lego block, tetapi kegiatan pembelajaran dapat dilaksanakan walupun belum maksimal. Pelaksanaan siklus I tindakan II kegiatan bermain berjalan dengan lancar pada tahapan ini keterampilan motorik haluas anak semakin meningkat hal ini dilihat anak dapat melakukan kegiatan bermain lego block. Pada pelaksanaan siklus II tindakan I anak semakin lues saat bermain, saat kegiatan bermain anak bekerjasama membuat bentuk mengunakan lego dan memainkan bersama-sama. Pada siklus II tindakan II kegiatan bermain berjalan lancar, anak dapat melakukan kegiatan secara mandiri tanpa bantuan guru, anak dapat melakukan kegiatan bermain lego block. Sebagaimana yang diungkapkan oleh Sumantri (2005, hlm. 121) Pengembangan keterampilan motorik halus akan berpengaruh pada kesiapan anak untuk menulis.

Secara keseluruhan berdasarkan hasil data siklus I dan siklua II dapat disimpulkan yang termasuk kategori belum berkembang (BB) pada observasi awal mencapai $100 \%$ pada akhir siklus I menjadi $0 \%$ dan menjadi 0\% pada akhir siklus II, kategori mulai berkembang (MB) pada observasi awal $0 \%$ menjadi $53 \%$ pada akhir siklus I dan pada akhir siklus II menjadi 8,3\%, kategori berkembang sesuai harapan (BSH) pada observasi awal $0 \%$ pada akhir siklus I menjadi $48 \%$ dan semakin meningkat pada akhir siklus II menjadi 91,7\%.

Peningkatan keterampilan motorik halus anak pada akhir siklus II setelah diberikan tindakan melalui permainan lego block. anak semakin terampi mengunakanjari jemari, dan kemampuan mengkoordinasi mata dengan tangan.

\section{SIMPULAN}

1.Profil kemampuan motorik halus anak kelompok A Pos PAUD Miana V Tahun ajaran 2015-2016 sebelum diberikan tindakan menunjukan bahwa secara umum rata-rata kemampuan motorik halus anak kelompok A masih dalam kategori belum berkembang. Hal ini di sebabkan oleh pemilihan metode pembelajaran dan kegiatan pembelajaran yang kurang menyenangkan dan kurang memberikan kesempatan kepada anak untuk melatih kemampuan motorik halusnya.

2.Pelaksanaan kegiatan permainan lego block sebagai salah satu upaya untuk meningkatkan kemampuan motorik halus anak, kegiatan dilakuakn dalam dua siklua. Pelaksanaan siklus I anak masih mengalami kesulita saat kegiatan bermain lego block, bentuk lego block yang dibuat anak terjatuh terus menerus dan hanjur, susunan lego block yang dibuat tidak tersabung satu sama lain karena saat membentuk anak kurang menekan lego block. Pelaksaan siklus II anak semakin baik saat melakukan kegiatan bermain lego block karena bentuk yang dibuat anak semakin kokoh dan tidak terjatuh. Permainan lego block dimainkan dengan cara anak mengambil lego block, memegang lego block dan menggengam lego block kemudian membentuk dengan cara menekan lego block dan mencabut lego block yang telah di susun. Kegiatan ini di lakukan untuk melatih kekuatan jari jemari anak dan koordinasi mata dan tangan anak. 
3.Peningkatan kemampuan motorik halus anak setelah diberikan tindakan melalui permainan lego block menunjukan hasil rata-rata kemampuan motorik halus anak meningkat cukup signifikan peningkatan kemampuan terlihat dari semakin banyaknya anak yang sudah mencapai tahap mulai betrkembang (MB) dan berkembang sesuai harapan (BSH). Dapat disimpulkan bahwa permainan lego block dapat meningkatkan kemampuan motorik halus anak kelompok A Pos PAUD Miana V.

\section{DAFTAR PUSTAKA}

Arifin, Z. (2009). Evaluasi Pembelajaran, Prinsip, Teknik, Prosedur. Bandung: P.T Remaja Rosdakarya.

Dini, P dan Daeng, Sari. (1996). Metode Mengajar di Taman Kanak-kanak. Jakarta: Depdikbud-Dikti, P2TK.

Eliyawati, Cucu. (2005). Pemilihan dan Pengembangan Sumber Belajar untuk Usia Dini. Jakarta : Depdiknas

Essa. (2010). Meningkatkan kereativitas anak usia dini melalui permainan lego. Skripsi PGPAUD FIP UPI : Tidak diedarkan

Hurlock, B.E. (1978). Perkembangan Anak. Jakarta: Erlangga.

Ismail, Andang. (2006). Education Games. Yogyakarta: Pilar Media.

Latif, M, Zukhairin, Zubaidah, R. \& Afandi, M. (2013). Orientasi Baru Pendidikan Anak Usia Dini. Jakarta: Kencana.

Masitoh. (2008). Bahan Ajar 19 Pengembangan Bahasa Untuk AUD. Bahan Ajar Diklat Tenaga PAUD Nonformal Tingkat Dasar. Bandung: Direktorat PTK PNF Ditjen PMPTK Departemen Pendidikan Nasional.

Mulyasa, E. (2012). Peraktik Penelitian Tindakan Kelas, Menciptakan Perbaikan dan Keseimbangan. Bandung: Rosda.

Rosita. (2014). Pengembangan Potensi Kognitif Anak Melalui Bermain Konstruktif dengan Lego di TK
Kartika V9 Pontianak. Tidak diterbitkan.

Samsudin. (2005). Penggembangan Motorik di Taman Kanak-kanak. Jakarta: Universitas Negri Jakarta

Sumantri. (2005). Metode Pengembangan Keterampilan Motorik Halus Anak Usia Dini. Jakarta:Depdiknas.

Sujiono, Bambang, dkk. (2008). Metode Pengembangan Fisik. Jakarta: Universitas Terbuka.

Suyanto, Selamet. (2005). Konsep Dasar Pendidikan Anak Usia Dini. Jakarta: Departemen Pendidikan Nasional Direktorat Jendral Pendidikan Tinggi.

Suyanto dan Jihad, A. (2013). Menjadi Guru Profesional (Strategi Meningkatkan Kualifikasi dan Kualitas Guru di Era Global). Jakarta: Esensi Erlangga Group.

Wahyudi, U dan Agustin. (2012). Penilaian Perkembangan Anak Usia Dini. Bandung : Refika Aditama

Yudha \& Rudyanto. (2005). Pembelajaran Kooperatif Untuk Meningkatkan Keterampilan Anak. Jakarta: Depdiknas.

Arikunto, S. (2010). Prosedur Penelitian Suatu Pendekatan Praktik. Jakarta: Rineka Cipta.

Anggani, Sudono. (2000). Sumber Belajar dan Alat Permainan. Jakarta. Grasindo 